\title{
Recent Insight into the Role of Fibrosis in Nonalcoholic Steatohepatitis-Related Hepatocellular Carcinoma
}

\author{
Antonio Sircana ${ }^{1}$, Elena Paschetta ${ }^{2}$, Francesca Saba $^{3}$, Federica Molinaro ${ }^{2}$ and \\ Giovanni Musso ${ }^{2, *}$ \\ 1 Department of Cardiology, Azienda Ospedaliero Universitaria, 07100 Sassari, Italy; ant.sircana@gmail.com \\ 2 HUMANITAS Gradenigo, University of Turin, 10132 Turin, Italy; elena.paschetta@alice.it (E.P.); \\ fede.molinaro@gmail.com (F.M.) \\ 3 Department of Medical Sciences, Cittàdella Salute, University of Turin, 10126 Turin, Italy; \\ francescasaba85@yahoo.it \\ * Correspondence: giovanni_musso@yahoo.it
}

Received: 1 February 2019; Accepted: 23 March 2019; Published: 9 April 2019

\begin{abstract}
Hepatocellular carcinoma (HCC) is one of the most widespread tumors in the world and its prognosis is poor because of lack of effective treatments. Epidemiological studies show that non-alcoholic steatohepatitis (NASH) and advanced fibrosis represent a relevant risk factors to the HCC development. However little is known of pathophysiological mechanisms linking liver fibrogenesis to HCC in NASH. Recent advances in scientific research allowed to discover some mechanisms that may represent potential therapeutic targets. These include the integrin signaling, hepatic stellate cells (HSCs) activation, Hedgehog signaling and alteration of immune system. In the near future, knowledge of fibrosis-dependent carcinogenic mechanisms, will help optimize antifibrotic therapies as an approach to prevent and treat HCC in patients with NASH and advanced fibrosis.
\end{abstract}

Keywords: hepatocellular carcinoma; non-alcoholic steatohepatitis; fibrosis; hepatic stellate cells; extracellular matrix; carcinogenesis

\section{Introduction}

As declared by the WHO (World Health Organization) Global Hepatitis Report [1], hepatocellular carcinoma (HCC) is the fifth most common cancer in the world and the second most common cause of death related to cancer in the last years. The main risk factors are chronic HBV and HCV infection, NAFLD/NASH, alcoholic hepatitis, and any disease leading to cirrhosis.

Non-alcoholic fatty liver disease (NAFLD), with global prevalence of 25\% [2], is the most common cause of chronic liver disease. Its clinical spectrum ranges from simple hepatic steatosis (in the absence of secondary causes) to non-alcoholic steatohepatitis (NASH), a more aggressive form with inflammation, hepatocyte injury and varying degrees of fibrosis [3,4].

NASH prevalence has increased exponentially over the years and probably in the next decades it will be the leading cause of liver transplantation in the western industrialized countries. Epidemiological data suggest that HCC attributed to viral infection is in decline, while cases of cryptogenic or NASH-related HCC are significantly increased [5]. Across studies, the risk of HCC is not uniform among patients with NASH, and it ranges between $2.4 \%$ and $12.8 \%$. If on the one hand it has been shown that patients with NASH can develop HCC in the absence of fibrosis or cirrhosis [6,7], on the other, it is shown that fibrosis plays a crucial role in causing HCC and its presence is correlated with poor prognosis [8,9]. A metanalisis of 17 cohort studies found a greater risk of HCC in NASH-cirrhosis cohorts than in NAFLD or NASH without fibrosis/cirrhosis [10]. HCC development 
is considered as result of different environmental risk factors that engage distinct genetic, epigenetic, and chromosomal alterations. It originates from chronic liver injury through a complex multistep process that involves several pathogenic mechanisms that contribute to carcinogenesis [11]. In humans, it is very complicated to identify the different molecular mechanisms underlying the pathogenesis of NASH and to understand how this evolves towards HCC. To overcome this problem, reproducible and representative preclinical models that are susceptible to genetic and functional analysis are used. Many NASH mouse models have been described, but some of them do not closely reflect human disease, thus hindering the efforts to definitively connect the various pathophysiological processes [12].

In this review we will discuss the latest findings on the pathophysiological mechanisms linking liver fibrogenesis to HCC in NASH and their potential therapeutic targets.

\section{Pathophysiological Mechanisms of NAFLD Progression}

NASH differs from simple steatosis by the presence of hepatocyte death, inflammation and various degrees of fibrosis. Cell death and inflammation play a leading role in disease progression, through HSCs' activation and the subsequent fibrosis. Lately, scientists put forward the idea ("the multiple parallel hits hypothesis") that progression from simple steatosis to NASH is the result of several disorders acting in parallel, including genetic predisposition, altered lipid metabolism, lipotoxicity, oxidative and endoplasmic reticulum stress, mitochondrial dysfunction, abnormal production of cytokines and adipokines, gut dysbiosis, and translocation of gut-derived LPS [13]. On this theory, hepatic inflammation constitute the "primum movens" of fibrosis progression in NASH. Genetic susceptibility and poor eating habits predispose to the development of insulin resistance and hepatic steatosis. In this context, lipotoxic metabolites of saturated fatty acids (SFA) can cause lipotoxicity, process that leads to cellular damage through excessive oxidative stress [14,15]. Damaged hepatocytes release DAMPs (damage-endogenous-associated molecular patterns) that activate pro-inflammatory signaling pathways via toll-like receptors (TLRs). Subsequent activation of Kupffer cells (KC) and inflammasome promote the massive release of pro-inflammatory, pro-fibrogenic cytokines and ligands. HSCs are then stimulated to produce high amount of extra-cellular matrix leading to progressive fibrosis [15]. KCs activation favors a pro-inflammatory microenvironment that triggers an adaptive immune response Th17-mediated. Moreover, chronic portal inflammatory infiltrate boosts a ductular reaction (DR) and hepatic progenitor cells (HPC) recruitment. All of these factors encourage progressive fibrosis that constitutes an imbalance between tissue injury and repair secondary to influence of vary inflammatory cells [16].

Acute inflammation constitutes a useful reaction to achieve tissues recovery by promoting regeneration. Conversely, chronic inflammation is maladaptive and provides a fertile soil to the development of liver fibrosis and HCC. Chronic injury triggers secretion of significant amounts of proinflammatory molecules including IL- 1 , IL- 6 , TNF- $\alpha$, lymphotoxin- $\beta$ that facilitate HCC development [17]. Activation of inflammatory signaling pathways and enhanced secretion of inflammatory molecules increase release of reactive oxygen species (ROS) by hepatocites. ROS can increase the tumor risk by mechanisms including DNA damage [11] and inhibition on immunosurveillance [18].

Although there is an established relationship between inflammation and fibrogenesis, it looks like that some inflammatory pathways selectively impact the tumorigenesis without affecting fibrosis. For instance, lymphotoxin- $\beta$ and neutrophils, promote the development of HCC but have no known role in hepatic fibrogenesis [19]. In diethylnitrosamine (DEN) mice model, obesity and chronic inflammation enhanced production of IL-6 and TNF and promoted HCC development through activation of the oncogenic transcription factor STAT3 [20]. In an elegant study, Grohmann et al. demonstrated how obesity-associated hepatic oxidative stress can independently contribute to the pathogenesis of NASH, fibrosis, and HCC via STAT-1 and STAT-3 signaling [21]. On the contrary, some inflammatory cells such as macrophages may promote both fibrosis and HCC [17]. Activation of TLR4 by gut-derived lipopolysaccharide (LPS) promotes both as well [22]. In the light of the above, 
it may be concluded that inflammation promotes hepatocarcinogenesis through fibrosis-dependent and -independent pathways.

\section{Fibrosis-Dependent Hepatocarcinogenesis}

Fibrogenesis is a multi-cellular response that occurs whenever there is hepatic damage with hepatocellular death. Acute liver injury triggers the inflammatory and fibrogenic cascade with activation of the HSCs that constitute the main source of extracellular matrix (ECM) rich in collagen I and III [23]. The aim is to restore the architecture and function of the organ after serious damage. In fact, inflammatory signals promote hepatic regeneration, inflammatory cells provide for removal of cellular debris, while fibrosis enable the mechanical stability [24].

However, wound healing responses grow into harmful ones when the underlying trigger cannot be removed and the hepatocellular death becomes chronic, causing chronic inflammation and the development of progressive liver fibrosis which distorts the hepatic and vascular architecture [25].

Several stimuli are directly hepatocarcinogenic and the inflammation-fibrosis-cirrhosis-HCC paradigm does not provide a causal link between fibrosis and HCC. In fact, fibrosis is just one component that can be difficult to separate from other carcinogenic insults.

Because most of the data is associative rather than causal, it could be legitimate to suppose that fibrosis could only be a spectator in the process of carcinogenesis. But in the last few years, researchers have sought to create representative models that reflect the response of the human liver to injury in order to provide a mechanistic link between these two phenomena.

Potential mechanisms of fibrosis-dependent hepatocarcinogenesis include enhanced integrin signaling by ECM; paracrine crosstalk between HSCs, hepatocytes and the ECM; augmented stromal stiffness; hypoxia; imbalance between matrix metalloproteinases and tissue inhibitor of metalloproteases; excessive activation of Hedgehog pathway signaling; autophagy, hepatic progenitor cells recruitment and dysregulation of the immune system (Figure 1).

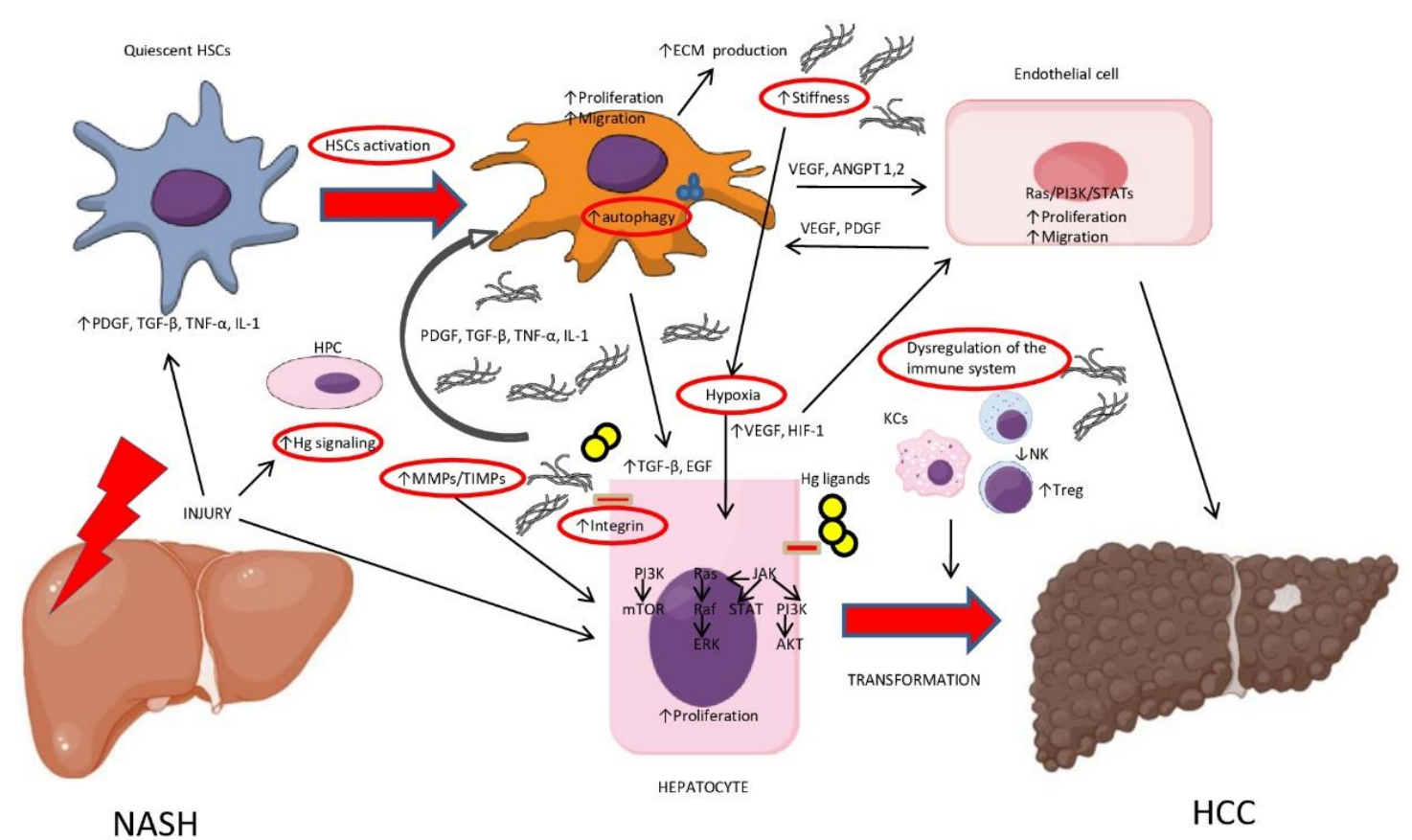

Figure 1. Fibrosis-dependent mechanisms of hepatocarcinogenesis in non-alcoholic steatohepatitis (NASH). Abbreviations: Hh, Hedgehog; PDGF, platelet derived growth factor; TGF- $\beta$, transforming growth factors- $\beta$; TNF- $\alpha$, tumor necrosis factor- $\alpha$; IL-1, interleukin-1; HSCs, hepatic stellate cells; ECM, extracellular matrix; PI3K, phosphatidylinositol 3-kinase; EGF, epidermal growth factor; MMPs, matrix metalloproteinases; TIMPs, tissue inhibitor of metalloproteases; VEGF, vascular endothelial growth factor; HIF-1, hypoxia-inducible factor 1; ANGPT, angiopoietin; HPCs, hepatic progenitor cells; KCs, Kupffer Cells. 


\subsection{Extracellular Matrix, Hepatic Stellate Cells, and Integrins}

In NASH, chronic hepatocellular damage and inflammation cause the activation of regenerative pathways and the proliferation of fibrogenic cells creating a micro-environment favorable to cellular survival and proliferation [26]. HSCs are 'quiescent' liver vitamin A-storing cells located in the perisinusoidal space. During the process of liver injury, the progressive release of pro-inflammatory molecules (platelet derived growth factor (PDGF), transforming growth factors- $\beta$ (TGF- $\beta$ ), tumor necrosis factor- $\alpha$ (TNF- $\alpha$ ), interleukin (IL)- 1 and several chemokine) fosters HSCs activation and successive differentiation into contractile and fibrogenic myofibroblasts, which are characterized by upregulation of mesenchymal markers ( $\alpha$-smooth muscle actin ( $\alpha$-SMA, ACTA2), desmin (DES), and collagen $\alpha 1(\mathrm{I}))$ [27]. Activated HSCs produce large amounts of fibrillar type I and III collagens, but also fibronectins, laminins, and fibrinogen, creating tight and highly crosslinked collagen bundles. An excessive production of ECM and reduction of ECM turnover is the typical characteristic of liver fibrosis. Changes in the composition and structure of the ECM have been shown to provoke cellular responses through the integrin family of transmembrane receptors, which play a crucial role in the activation of TGF- $\beta$ and fibrogenic response [28,29]. Integrins modulate proliferation, differentiation and survival through the activation of Hedgehog signaling [30] and other intracellular specifics pathways, including protein kinase C, phosphatidylinositol 3-kinase (PI3K) and mitogen-activated protein kinases (MAPK) [31]. Integrins may also be involved in signal transduction during angiogenesis by stimulating the intracellular signaling molecules. The integrin expression pattern are different and up-regulated in primary and metastatic HCC tissues compared to normal hepatocytes. In human HCC cell lines, integrins $\alpha 1 \beta 1$ and $\alpha 2 \beta 1$ inhibition reduces migration induced by profibrotic growth factors including TGF- $\beta 1$, epidermal growth factor (EGF) and fibroblast growth factor (FGF) [32]. However there are disagreements about the role of these receptors in the onset and progression of HCC [33]. Recently, Zheng et al. showed that collagen I promotes HCC cells proliferation by regulating the $\beta 1 /$ FAK integrin pathway in murine models of NAFLD/NASH [34].

ECM proteins interact even with DDR proteins (discoidin domain receptor). Of these, DDR2 is a tyrosine kinase of the type I collagen that promotes epithelial-mesenchymal transition (EMT), an important mechanism that favors the malignant transformation of epithelial cells [35]. In animal model of pulmonary fibrosis, treatment with an antisense oligonucleotides (ASO) or with DDR2 inhibitors, prevents myofibroblast activation and angiogenesis [36].

\subsection{Matrix Stiffness}

In liver fibrosis, excessive collagen deposition increases the stiffness of the ECM, which in turn promotes the further increase in collagen secretion by HSCs [37]. A meta-analysis of 17 prospective cohort studies including 7058 patients found that increasing liver stiffness (measured using transient elastography) was associated with higher risk of HCC development [38].

Higher matrix stiffness, caused by copious matrix protein deposition and crosslinking, plays an important role in cell growth, proliferation, motility and tumor metastasis in several tissues [39,40].

Experimental data suggest that matrix stiffness might modulate HCC cells proliferation, invasion, angiogenesis through several pathways including extracellular signal-regulated kinase (ERK), protein kinase $\mathrm{B}(\mathrm{PKB} / \mathrm{Akt})$, signal transducer and activator of transcription 3 (STAT3), integrin $\beta 1 /$ GSK-3 $\beta / \beta$-catenin [41] $\beta 1$-integrin/focal adhesion kinase (FAK) [42], and $\beta 1$-integrin/phosphatidylinositol-3- kinase (PI3K)/Akt signaling pathways [43]. Recent data indicate that ECM stiffness could promote tumorigenesis through activation of Hippo-YAP/TAZ signaling pathway, a critical regulator of cell proliferation, differentiation and apoptosis [19].

Recently, You et al., showed that matrix stiffness could take an active part in the process of stemness regulation through integrin $\beta 1 / \mathrm{Akt} / \mathrm{mTOR} / \mathrm{SOX} 2$ signaling pathway [44]. 


\subsection{Matrix Metalloproteinases and Tissue Inhibitor of Metalloproteases}

Matrix metalloproteinases (MMPs), (calcium-dependent enzymes secreted mainly by HSCs but also by macrophages) and their endogenous inhibitors, tissue inhibitor of metalloproteases (TIMPs) regulate the ECM turnover [45]. In animal models, an imbalance between MMPs and TIMPs concentrations is associated not only with an alteration of ECM homeostasis, but also with alterations of various biological activities that increase the risk of developing rheumatoid arthritis, atherosclerosis, nephritis, fibrosis, cirrhosis and cancer [46]. In fact, MMPs degrade the stroma, can remove the extracellular receptors on the cell surface and are also involved in the turnover of non-matrix substrates: MMPs liberate growth factors, ligands and citokines from the ECM. In addition, they are involved in the metabolism of macromolecules (proteins, lipids, carbohydrates) and regulation of growth and cellular differentiation [47].

Animal and human data suggest that MMPs and TIMPs are implicated in phenomena such as angiogenesis, proliferation of HSCs and progression of hepatocytes from dysplasia to HCC [48]. Indeed, TIMP-1 inhibits the tumor apoptosis via SDF-1/PI3K/AKT signaling [49]. MMP-1 production enhances proliferation, invasion and fibrosis in NASH. Moreover, serum MMP-1 levels reflect disease activity and may be used as a potential biomarker for monitoring the progression of disease [50]. MMP1 and MMP7 promote re-epithelialization and smooth muscle cells de-differentiation via PAR-1; MMP8 activates HSCs; MMP3 promotes the HGF-induced invasion of human HCC; MMP-19 is involved in TGF- $\beta$ signaling; MMP-25 attenuates alpha-1 proteinase inhibitor facilitating the migration. In hepatoma cells, expression of MT1-MMP, MMP-2, and MMP-9 facilitates stromal invasion [45]. These data indicate that the imbalance between MMPs expression and their endogenous inhibitors could play a key role in HCC development. Researches investigating potential drug therapies targeting MMPs and TIMPs in HCC are currently ongoing.

\subsection{Hypoxia}

Abundant ECM deposition and subversion of normal architecture during the fibrogenic process creates altered blood flow that reduces metabolic exchange of oxygen in the liver parenchyma [51]. Hypoxia leads to activaction of specific signalling pathways [52] (PI3K-Akt and MAPK pathways) and upregulation of angiogenic factors including vascular endothelial growth factor (VEGF) and [53] hypoxia-inducible factor 1 (HIF-1) [54]. These facilitates tumor growth, angiogenesis, EMT and metastasis [55]. High levels of HIF-1 and VEGF correlate with the aggressiveness of HCC and with worst prognosis [56].

Tuftelin1 (TUFT1) is an acidic protein expressed in several tissues and exerts multifunctional roles [57]. New study in human with HCC found that hypoxia enhances TUFT1 expression through HIF-1 $\alpha /$ miR-671-5p/TUFT1/AKT signaling pathway [58]. TUFT1 furthered HCC cell growth and metastasis in vitro and in vivo by activating the Ca2 /PI3K/AKT pathway. In this study TUFT1 knockdown minimized the promoting effects of hypoxia on tumor growth and metastasis, suggesting that TUFT1 may represent a new potential therapeutic target for HCC treatment.

\subsection{Hedgehog Signaling}

During embryogenesis, the Hedgehog $(\mathrm{Hh})$ pathway represents an essential signaling mechanism that modulates many aspects of cell differentiation and tissue development [59]. In healthy adult liver, there is a low expression of Hh ligand and high expression of Hh ligand antagonist, so there is almost no Hh activity [60]. Liver injury, in contrast, is associated with elevated Hh signaling that stimulates liver regeneration [61]. Several studies show that in HCC there is an excessive activation of Hh signaling and this promotes proliferation, migration and invasion of HCC cells [62]. A recent study claims there is interplay between Sonic Hedgehog (Shh) and TGF- $\beta 1$ in hepatic inflammatory reactions. Secreted Shh may involve activation of TGF- $\beta 1$ and subsequent activation of HSCs, which together promote the progression of human NASH [63]. In Mdr2 ${ }^{-}{ }^{-}$mice with chronic liver fibrosis, Philips et al. 
studied the role of the Hh pathway in hepatocarcinogenesis [64]. In this work, Hh pathway activation promotes both liver fibrosis and hepatocarcinogenesis while inhibition of Hh signaling reverses both processes. Authors suggest that the carcinogenic effect of Hh could be mediated by augmented myofibroblast activation and fibrosis [64].

\subsection{Hepatic Progenitor Cells}

Hepatic progenitor cells (HPCs) are resident stem cells located at the level of Canals of Hering and when activated promote tissue turnover and liver regeneration [65]. Chronic hepatocyte injury is associated with HPCs activation and enhancement of several pathways identified in liver cancer, including Hg, canonical Wnt signaling and Notch [66]. Proliferation and differentiation of HPCs, depend on the up-regulation of these pathways [67]. Studies in NASH patients claimed that HPCs activation and the expansion of ductular reaction (DR) were independently correlated with progressive fibrosis both in adult and children [68,69]. During hepatic necrosis, proliferating HPCs augment their expression of profibrogenic factors while DR cells produce PDGF, TGF- $\beta$, Sonic $\mathrm{Hg}$ and activate HSCs [65]. These findings support the idea that HPCs activation could contribute to the initiation and sustain HCC.

\subsection{Autophagy}

Autophagy is an evolutionarily conserved cellular process for lysosomal degradation of damaged cell components. Cellular organelles, lipid droplets, large protein aggregates are sequestered and degradated, while amino acids generated are used for producing energy [70]. Autophagy is a complex dynamic process regulated by several signaling pathways involved in cellular proliferation and apoptosis such as PI3K/Akt/mTOR and AMPK pathway [71]. In NASH, activated HSCs develop autophagic activity as a mechanism of lipid droplet degradation from which obtain energy support for their activation. In fact, treatment with an autophagy inhibitor prevents HSCs activation in vitro while reduces lipid droplet degradation [72]. This suggests that autophagy could be a target for the treatment of NASH and fibrosis. In rats, curcumin treatment leads to protection against toxin-induced HCC through induction of autophagic pathway and inhibition of apoptosis [73].

However the role of autophagy on HCC development is controversial. A study in autophagy-deficient mice with mosaic deletion of Atg5, showed the 'double-edged sword' of autophagy, since it is important for suppression of tumorigenesis in the liver but at the same time it promotes tumor progression because of accumulation of harmful protein aggregated [74]. Conversely, Sun et al. found that autophagy-deficient Kupffer cells promote liver inflammation, fibrosis, and HCC by enhancing mitochondrial ROS- NF-kB-IL1 $\alpha / \beta$ pathways [75]. These data recommend that targeting autophagy for the treatment of NASH-fibrosis and HCC should require cell-specific autophagy inhibitors.

\subsection{Dysregulation of the Immune System}

The innate and adaptive immune system are essential for the identification and suppression of transformed cells. In NASH, liver injury stimulates the activation of several types of immune cells [76].

Kupffer cells (KCs) could play a important role in initiation and progression of inflammation and fibrosis. Liver biopsies of patients with NAFLD found a higher expansion of KCs than in controls. This phenomenon precedes the recruitment of other inflammatory cells, in fact macrophage infiltration occurs in more advanced inflammatory stages of the disease [77]. In the early phase of NAFLD, pathogen-associated molecular patterns (PAMPs), changes in gut microbiota, increase intestinal traslocation of bacteria and toxins can activate KCs [78], which secrete TGF- $\beta$, TNF- $\alpha$, pro-inflammatory cytokines such as CCL2, ROS and activate inflammasomes [76]. Activation of NLRP3 fosters secretion of IL-1 $\beta$, IL-18, and IL- 6 which in turn promote disease progression and HCC development [79]. Furthermore, damaged hepatocytes are be able to activate KCs through cell stress pathways such as c-Jun N-terminal kinase (JNK) and release of DAMPs factors which promote inflammation via TNF- $\alpha$, nuclear factor (NF)- $\mathrm{KB}$ and TLR signaling activation $[78,80]$. In addition, 
in condition of hypoxia KCs can be activated by HIF-1 $\alpha$ [81]. Thus far, the role of KC in HCC is not fully clarified and is being investigated.

The role of dendritic cells (DC) in NASH is not clear. Existing experimental data are inconsistent perhaps because differences in the NASH models utilized or the diets administered in the studies [82].

The role of neutrophils is not also entirely clarified. However increase in liver neutrophils has been reported in human with NASH [83], and the degree of infiltration is correlated with severity of disease [84]. Neutrophils could contribute to NASH progression and carcinogenesis via Myeloperoxidase (MPO)-related mechanisms [84].

Natural killer (NK) cells are significantly elevated in NASH livers, compared to normal healthy control. Their activation during injury may be due to the higher levels of several cytokines including IL-12, IL-18, and IFN- $\gamma$ [85]. In the early phases of disease, NK cells act against fibrosis development through IFN $\gamma$ and by inducing apoptosis of HSCs via TRAIL and FasL, while in the late stages, NK cell function is compromised leading to further increases the ECM deposition promoting HCC development [86]. NK cells play a critical role in the immune surveillance of liver tumors [87]. Several mechanisms has been proposed to explain the decrease in the NK cell functions that are associated with advance fibrosis and HCC. These include TGF $\beta$-mediated inhibition, phagoctyosis of NK cells by HSCs, inability to make target-cell contact and the dysregulation of activating ligands [88]. However, further studies are required to clarify the role of NK cells in the carcinogenesis process during fibrosis.

NKT cells increase in human NASH with advanced fibrosis but their role in hepatocarcinogenesis is still unclear. They can secrete IL-4, IFN- $\gamma$, and TNF- $\alpha$ [89] as well as promote steatosis through signaling via the lymphotoxin-like inducible protein LIGHT, activate HSCs, enhance Hh signaling then fibrosis [76]. The results of experimental data in HCC are in contrast. Indeed, NKT cells may both play an anti-tumor role and promote tumor tolerance [76].

In a choline-deficient high-fat diet mice model, Wolf et al., described intrahepatic activation of $\mathrm{CD}^{+} \mathrm{T}$ cells, NKT cells, and inflammatory cytokines, similarly to NASH patients [83]. CD8 ${ }^{+} \mathrm{T}$ cells and NKT cells synergistically induced steatosis, NASH and HCC development. NKT cells promote steatosis via lymphotoxin (LT)-like inducible protein LIGHT, while CD8(+) T cells cause liver damage in a LT $\beta$ R-independent manner. CD8+ cytotoxic T lymphocytes kill their target cells not only through their two mayor cytotoxic mechanisms (perforin/granzyme-mediated, and Fas ligand (FasL)-mediated) [90], but also by secretion of IFN- $\gamma$ and TNF- $\alpha$ [91]. However, depletion of CD8+ T lymphocytes in different experimental mice models produced varying results on onset and progression of HCC $[92,93]$.

Previous studies reported that CD4+ T lymphocytes are capable to inhibit HCC initiation and favor tumor regression through the expression of chemokines [94]. Study in mouse models of NAFLD and HCC, found that dysregulation of lipid metabolism induces a ROS-mediated selective loss of intrahepatic CD4+ T but not of CD8+ T cells, leading to tumorigenesis [18]. An analysis of 547 patients with HCC showed that progressive loss of $\mathrm{CD} 4^{+}$cytotoxic $\mathrm{T}$ cells was significantly correlated with an advanced stage of disease and poor prognosis [95].

Regulatory T cells (Treg) recruitment may impair the function of $\mathrm{CD}^{+} \mathrm{T}$ cells and promote cancer progression. In a DEN-induced HCC mouse model, TGF- $\beta$ promoted Treg cell differentiation, and this was identified as a major inhibitory mechanism of CD8+ T cells [96]. An increased recruitment of Treg cells correlated with poor prognosis [97].

In humans, NASH with advanced fibrosis is associated with high circulating $\operatorname{Ig} \mathrm{A}^{+}$cells levels that build up in fibrotic liver [98]. These cells can interfere with activation of cytotoxic $\mathrm{CD} 8^{+} \mathrm{T}$ lymphocytes through programmed death ligand 1 (PD-L1) and interleukin-10, and promote HCC development [99]. In mice, PD-L1 blockade induces cytotoxic T-lymphocyte-mediated regression of established HCC [93].

Although the mechanisms are not yet well-known, we can state that immune system may play a 'dual and opposite role' in the development and progression of HCC. However, extensive studies are needed. 


\subsection{Crosstalk between NASH and Hepatocellular Carcinoma}

HSCs, fibroblasts, immune cells, endothelial and mesenchymal stem cells as well as cytokines, growth factors and ECM constitute the liver tumor microenvironment. The results of numerous studies provide evidence that the cross-talk between tumor cells and their surrounding microenvironment is essential for cell growth, proliferation, EMT and metastasis [100] (Table 1).

Activated HSCs secrete several molecules including PDGF-B and PDGF-C, TGF- $\alpha$, TGF- $\beta$, EGF, VEGF, angiopoietin-1 and -2, hepatocyte growth factor (HGF), stromal-derived factor-1alpha (SDF-1), Wnt ligands, interleukin-6 (IL-6) and epimorphin (EPM) [101]. These mediators are important pro-angiogenic, proliferative, and regenerative citokines that create a favorable microenvironment facilitating tumor initiation and progression [56]. In fibrotic liver, these molecules are passively sequestered by the ECM favoring the bidirectional interaction between endothelial, stromal cells and hepatocytes in an autocrine/paracrine manner [102]. Therefore, HSCs can be the target of the molecules produced by themselves. Activated HSCs show increased expression of different receptors for soluble cytokines, including PDGF that is the most potent proliferative cytokine [103]. Generally, expression of PDGF receptors by HSCs is low but drastically increases during inflammation, NAFLD and NASH [104]. Induction of $\beta$-PDGF receptors leads to activation of the Fas-MAPK pathway and release of intracellular calcium ions that activate PKC family members then activation of a more contractile and fibrogenic phenotype of HSC [105]. In mice model, hepatic over-expression of PDGF-C induces changes in gene expression, inflammation, progressive fibrosis, neoangiogenesis, and dysplasia. In patients with NASH, Wright et al., found a important correlation between PDGF-CC levels in liver and severity of disease [106]. Thus, PDGF-C could be more crucial in modulating the microenvironment to promote HCC development in a paracrine manner than in promoting direct carcinogenic effects on hepatocytes. In vitro, EPM promotes HCC cells invasion and metastasis by activating MMP-9 expression through the FAK-ERK pathway [107].

New data suggest that HSCs could promote HCC progression through the production of IL-1 $\beta$, via a mechanism that seems to be dependent on PKR activation [108].

Cancer-associated fibroblasts (CAFs) are the most abundant cell type of the tumor stroma and are similar in morphology and molecular expression profiles to the myofibroblasts (HSCs) that are activated during the wound repair process [109]. However origin of the CAFs in HCC is obscure. Indeed, they can originate from HSCs, migrated bone-marrow stem cell and EMT [110]. Thus far, there is little evidence that HSCs and CAFs drive the malignant transformation of hepatocytes, but it is established that these stromal cells create a microenvironment that supports the growth of dysplastic hepatocytes and HCC [19]. Studies in vitro suggest that HGF could be a mediator of tumor-stromal interactions through which CAFs regulate the proliferation and invasion of HCC cells [111].

MMP-2 together with MMP-9 has a fundamental role on degrading type IV collagen that is the most abundant component of ECM. Feng et al., found that co-cultures of vascular endothelial and HCC HepG2 cells increased expression of MMP-2 and MMP-9 which enhanced the invasion ability of the HepG2 cells [112].

Angiogenesis provides a source of oxygen, nutrients and is indispensable for tumor growth and metastasis [113]. Both in phase of tumor development and progression, several molecular pathways are involved in the induction of angiogenesis and in the preservation of metastasis supporting vascular networks. VEGF represents a fundamental element that controls most of mechanisms of tumor-induced angiogenesis, because stimulates vascular sprouting, tip cells formation, sprout elongation and lumen formation [114].

In this context, tumour cells may activate Treg cells and promote immune tolerance by inhibiting the anti-tumorigenic effects of NK and $\mathrm{CD} 8^{+} \mathrm{T}$ cells [115]. 
Table 1. Main mechanisms involved in NASH progression and hepatocellular carcinoma (HCC) development.

\begin{tabular}{|c|c|c|}
\hline Factor & Mechanism & Biological Effects \\
\hline Inflammation & $\uparrow$ PDGF, TGF- $\beta$, TNF- $\alpha$, IL- 1 and chemokines & HSCs and KCs activation \\
\hline Activated HSCs & $\begin{array}{l}\text { - } \quad \text { Type I and III collagens, fibronectins, laminins, } \\
\text { fibrinogen secretion } \\
\text { - } \uparrow \text { TGF- } \beta_{1}, \text { TGF- } \alpha \text {, PDGF, FGF, EGF, VEGF, } \\
\text { ANGPT } 1-2, \text { HGF, SDF-1, Wnt ligands, } \\
\text { IL-6, EPM }\end{array}$ & $\begin{array}{ll}\text { - } & \downarrow \text { MMPs } \downarrow \text { and ECM turnover } \\
\text { - } & \uparrow \text { Stiffness } \\
\text { - } & \uparrow \text { Hypoxia } \\
\text { - } & \downarrow \text { NK cell functions } \\
\text { - } & \uparrow \text { Integrin signaling } \\
\text { - } & \uparrow \text { HSCs activation } \\
\text { - } & \uparrow \text { Angiogenesis }\end{array}$ \\
\hline$\uparrow$ Stiffness & $\begin{array}{ll}\text { - } & \uparrow \text { Collagen secretion } \\
\text { - } & \text { Activation of ERK, PKB/Akt, STAT3, integrin } \\
& \beta 1 / \text { GSK-3 } \beta / \beta \text {-catenin; } \beta 1 \text {-integrin/FAK and } \\
& \beta 1 \text {-integrin/PI3K/Akt signaling pathways } \\
\text { - } & \text { Activation of Hippo-YAP/TAZ signaling } \\
\text { pathway and integrin } \beta 1 / \mathrm{Akt} / \mathrm{mTOR} / \mathrm{SOX} 2 \\
\text { signaling pathway }\end{array}$ & $\begin{array}{ll}\text { - } & \uparrow \text { Cell proliferation, motility and } \\
\text { tumor metastasis } \\
\text { - } \quad \downarrow \text { Apoptosis } \\
\text { - } \quad \text { Stemness dysregulation } \\
\text { - } \quad \downarrow \text { NK cell functions }\end{array}$ \\
\hline Integrins & - $\quad \uparrow$ Hedgehog signaling, PI3K, MAPK pathways & $\begin{array}{ll}- & \uparrow \text { Proliferation, survival } \\
\text { - } & \uparrow \text { Angiogenesis }\end{array}$ \\
\hline $\begin{array}{l}\text { MMPs/TIMPs } \\
\text { imbalance }\end{array}$ & $\begin{array}{ll}\text { - } & \uparrow \text { Release of growth factors, ligands and } \\
& \text { citokines from the ECM } \\
\text { - } & \uparrow \text { TGF- } \beta \text { signaling } \\
\text { - } & \downarrow \text { Alpha-1 proteinase inhibitor } \\
\text { - } & \downarrow \text { SDF-1/PI3K/AKT signaling }\end{array}$ & $\begin{array}{ll}\text { - } & \downarrow \text { ECM turnover } \\
\text { - } & \uparrow \text { HSCs activation } \\
\text { - } & \text { Progression of hepatocytes from } \\
& \text { dysplasia to HCC } \\
\text { - } & \uparrow \text { Migration } \\
\text { - } & \uparrow \text { Invasion } \\
\text { - } & \downarrow \text { Apoptosis }\end{array}$ \\
\hline Hypoxia & $\begin{array}{l}\text { - } \quad \text { Activation of PI3K-Akt and MAPK pathways } \\
\text { - } \quad \uparrow \text { VEGF and HIF-1 } \\
\text { - } \quad \uparrow \text { TUFT1 } \rightarrow \text { Ca2 /PI3K/AKT pathway }\end{array}$ & $\begin{array}{ll}\text { - } & \text { KCs activation } \\
\text { - } & \uparrow \text { Angiogenesis, } \\
\text { - } & \uparrow \text { EMT } \\
\text { - } & \uparrow \text { Tumor growth and metastasis }\end{array}$ \\
\hline Hedgehog $(\mathrm{Hg})$ & - $\quad \uparrow$ TGF- $\beta 1$ and HSCs activation & $\begin{array}{ll}\text { - } & \text { NASH progression } \\
\text { - } & \uparrow \text { Proliferation } \\
\text { - } & \uparrow \text { Migration and invasion of HCC cells }\end{array}$ \\
\hline $\begin{array}{l}\text { HPCs and } \\
\text { ductular } \\
\text { reaction (DR) }\end{array}$ & $\begin{array}{l}\text { - } \quad \uparrow \mathrm{Hg}, \text { Wnt signaling and Notch pathways } \\
\text { - } \quad \uparrow \mathrm{PDGF}, \mathrm{TGF}-\beta \text {, and HSCs activation }\end{array}$ & - $\quad$ NASH progression \\
\hline Autophagy & $\begin{array}{ll}\text { - } & \mathrm{PI} 3 \mathrm{~K} / \mathrm{Akt} / \mathrm{mTOR} \text { and AMPK pathway } \\
\text { - } & \text { Mitochondrial ROS- NF-kB-IL1 } \alpha / \beta \text { pathways }\end{array}$ & - $\quad \pm$ Cellular proliferation and apoptosis \\
\hline $\begin{array}{l}\text { Kupffer Cells } \\
\text { (KCs) }\end{array}$ & $\begin{array}{l}\text { - } \quad \uparrow \text { TGF- } \beta, \text { TNF- } \alpha, \text { CCL2, ROS } \\
\text { - } \quad \text { Activation of NLRP3 } \rightarrow \text { IL-1 } \beta, \text { IL-18 and IL- } 6\end{array}$ & 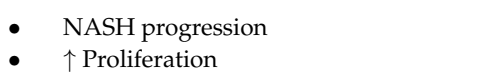 \\
\hline$\downarrow$ NK cells & $\begin{array}{ll}- & \downarrow \text { IFN } \gamma \\
\text { - } & \downarrow \text { Apoptosis of HSCs }\end{array}$ & $\begin{array}{ll}\text { - } & \uparrow \text { ECM deposition } \\
\text { - } & \downarrow \text { Tumor surveillance }\end{array}$ \\
\hline NKT cells & $\begin{array}{l}\text { - } \quad \text { IL-4, IFN- } \gamma \text {, and TNF- } \alpha \\
\text { - } \quad \text { Regulate HSCs activation and Hh signaling }\end{array}$ & - Anti-tumor role or tumor tolerance \\
\hline$\uparrow$ Treg cells & - $\quad \downarrow$ NK and CD8+ T cells & - $\quad \downarrow$ Tumor surveillance \\
\hline
\end{tabular}

Hh, Hedgehog; PDGF, platelet derived growth factor; TGF- $\beta$, transforming growth factors- $\beta$; TNF- $\alpha$, tumor necrosis factor- $\alpha$; IL-1, interleukin-1; HSCs, hepatic stellate cells; ECM, extracellular matrix; PI3K, phosphatidylinositol 3-kinase; EGF, epidermal growth factor; MMPs, matrix metalloproteinases; TIMPs, tissue inhibitor of metalloproteases; VEGF, vascular endothelial growth factor; HIF-1, hypoxia-inducible factor 1; ANGPT, angiopoietin; HPCs, Hepatic progenitor cells; EPM, epimorphin. 


\section{Therapeutic Perspective}

Although numerous drugs have been indagated, none of them have been validated in phase III.

Trials and so far, there is no medicament authorized by regulatory authorities for management of NASH. However, several molecules were shown to be effective in preclinical studies and some of these are currently being examined in humans.

TGF- $\beta$ induces a complex modulation of gene expression because it can use several extracellular signals and adhesion molecules [116]. It promotes liver inflammation, activation of HCSs then fibrosis, EMT and growth of HCC [117]. TGF- $\beta$ is regarded as pivotal molecule in HCC tumorigenesis since it, secreted by HSCs or by transformed hepatocites, may inhibits NK cell functions [118], and may control the secretion of other cytokines [119]. In human HCC cell lines, treatment with TGF- $\beta$ inhibitor LY2109761 stops migration and invasion by upregulating E-cadherin [120], inhibits neo-angiogenesis, reduces tumor growth and metastasis of HCC cells by inhibiting CAFs proliferation [121]. Galunisertib (LY2157299) is another promising antifibroticTGF- $\beta$ inhibitor that inhibits SMAD2 phosphorylation and blocks the collagens deposition promoting their degradation [122]. Large RCT in humans are needed.

Chemokines, regulate many functions of hepatocytes, endothelial cells, HCSs, and circulating immune cells. Interactions between C-C chemokine receptors (CCR2, CCR5,CCL2,CCL5,) and their ligands, promote fibrogenesis by HSCs activation and macrophage recruitment in the liver [123]. In preclinical models of NASH, Cenicriviroc (CCR2/CCR5 antagonist) improved hepatic inflammation and fibrosis [124]. These results have been confirmed in the recent phase 2b CENTAUR study [125]. A phase III trial to evaluate the efficacy of this drug is ongoing.

Sorafenib is multikinase inhibitor of VEGFR and PDGFR approved for the treatment of HCC where increases overall survival compared to placebo [126]. In NASH rodent models, sorafenib treatment decreased inflammation, angiogenesis, HSCs activation, collagen deposition, and hepatic fibrosis [127]. It may be considered for the treatment of NASH in humans. Further studies are warranted.

Inhibition of collagen synthesis may represent a potential therapy for fibrotic liver diseases. Recent study in rats found that cationic lipid nanoparticles loaded with small interfering RNA to the procollagen $\alpha 1$ (I) gene administration, provoked specific inhibition of type I collagen synthesis without visible side effects [128]. So far, no data on human are avaiable.

In recent years, results of phase 2-3 trials found that treatment with integrin inhibitors was ineffective for the treatment of various cancers including HCC [129]. However, it has recently been discovered that $\alpha \mathrm{v}$ integrins play a key role in the fibrogenesis in the liver, skin, kidney, and lung, although many mechanisms are still unknown [130]. Many Phase 1-2 trials are underway to evaluate the efficacy of integrin inhibitors in reversing the fibrosis process (ClinicalTrials.gov).

Hh dysregulation represent a novel mechanism for hepatic fibrosis and hepatocarcinogenesis, and may considered as potential therapeutic target for patients with NASH or HCC. Recently Hh-inhibitor LDE225 was approved for the treatment of basocellular carcinoma [131]. Phase 1 study to test the safety and determine the maximum safe dose of LDE225 in patients with HCC is ongoing (NCT02151864).

In fibrotic livers, the immunosuppressive function of the fibrosis-stimulated Ig $\mathrm{A}^{+}$cells probably depends on the expression of PD-L1 and IL-10, which may promote CTL dysfunction [132]. Programmed death 1 (PD-1) inhibitors reverse $\mathrm{CD} 8^{+} \mathrm{T}$ cells dysfunction and can therefore represent a treatment option for patients with advanced HCC. Nivolumab is a PD-1 inhibitor approved for the treatment of several malignancy including melanoma, non-small cell lung cancer and renal carcinoma. In a phase 1/2 trial, Nivolumab showed a manageable safety profile and no side effects were observed in patients with advanced HCC [133]. Several phase 2/3 Trial are ongoing (ClinicalTrial.gov).

\section{Conclusions and Discussion}

Growing evidence suggest a mechanistic link between fibrotic microenvironment and the HCC development. However, the lack of representative animal models is hampering the efforts to understand the pathophysiological mechanisms in NASH-related HCC. NASH is a complex and 
extremely heterogeneous metabolic disease and despite several mouse models can mimic disease; rarely, they replicate the pathogenic sequence of human NASH-HCC. These features can explain the conflicting results among studies using different animal models.

There are 3 main categories of murine NASH models: diet models, toxins/diet-based models, and genetic/diet models [12]. For instance, a methionine/choline-deficient (MCD) diet produces histological features of NASH, but rodents treated with this diet do not develop insulin resistance [134]. A western diet (WD), induces NASH, obesity and insulin resistance but disease does not progress to advanced fibrosis [135]. Streptozotocin (STZ) and diethylnitrosamine (DEN) + HFD models, develop obesity, insulin resistance, type 2 diabetes, mild fibrosis and HCC. However an independent carcinogenic effect of toxins cannot be excluded [12]. Tsuchida et al. studied a new mice model where mice were treated with WD and weekly dosing of carbon tetrachloride (CC14) [136]. This interesting model reproduces the progressive stages of human NAFLD, from simple steatosis, to inflammation, fibrosis, and HCC. In addition, the model replicates gene expression and immune abnormalities of human disease [136]. Nevertheless, previous reports showed that CCl4 is a potent hepatotoxin that can cause genotoxicity and oxidative DNA damage in rats [137]. Numerous genetically modified mice that are susceptible to NASH and HCC development have been described but most of them do not resemble the human progression of disease. HFD-fed MUP-uPA and DIAMOND mice develop human NASH-like disease and almost all of them progress to HCC [12]. However, in these models HCC development is significantly slower than in toxins/diet-based models. Moreover, the mutational landscape of these mice differs significantly from mouse to mouse [93].

Aim of research is overcoming this gap in order to identify a model that best replicates the several aspects of NASH-driven HCC, because studies that are performed with inappropriate models generate misleading results that delay progress in this field.

The understanding of the multiple molecular mechanisms involved in fibrogenesis make it possible to identify various therapeutic targets including cytokines, chemokines, HSCs, Hedgehog pathway signaling and other potential targets, for the purpose of reversing the fibrosis process. A better understanding of the underlying pathophysiological mechanisms could also be useful for identify non-invasive biomarkers of NASH and fibrosis because liver biopsy as the diagnostic "gold standard" it is not without risk. Moreover, imaging techniques can detect steatosis but not steatohepatitis.

The results of preclinical experiments are promising, as they have shown that it is possible to reverse the fibrogenesis process. However, it is not that simple to verify in humans. Furthermore, it is desiderable that future research establishes whether a reduction of fibrosis in patients with NASH is effective in HCC prevention [138].

Funding: This research received no external funding.

Conflicts of Interest: The authors declare no conflict of interest.

\begin{tabular}{ll}
\multicolumn{2}{l}{ Abbreviations } \\
NASH & Non-alcoholic steatohepatitis \\
NAFLD & Non-alcoholic fatty liver disease \\
HCC & Hepatocellular carcinoma \\
HSCs & Hepatic stellate cells \\
ECM & Extracellular matrix \\
PDGF & Platelet derived growth factor \\
TGF- $\beta$ & Transforming growth factors- $\beta$ \\
ROS & Reactive oxygen species \\
KCs & Kupffer cells \\
DC & Dendritic cells \\
TLR & Toll-like receptor \\
NF & Nuclear factor
\end{tabular}




$\begin{array}{ll}\text { SFA } & \text { Saturated fatty acids } \\ \text { DAMPs } & \text { Damage-endogenous-associated molecular patterns } \\ \text { PAMPs } & \text { Pathogen-associated molecular patterns } \\ \text { DR } & \text { Ductular reaction } \\ \text { HPCs } & \text { Hepatic progenitor cells } \\ \text { DEN } & \text { Diethylnitrosamine } \\ \text { LPS } & \text { Lipopolysaccharide } \\ \text { DDR } & \text { Discoidin domain receptor } \\ \text { PI3K } & \text { Phosphatidylinositol 3-kinase } \\ \text { MAPK } & \text { Mitogen-activated protein kinases } \\ \text { ERK } & \text { extracellular signal-regulated kinase } \\ \text { STAT } & \text { signal transducer and activator of transcription } \\ \text { FAK } & \text { focal adhesion kinase } \\ \text { JNK } & \text { Jun N-terminal kinase } \\ \text { VEGF } & \text { Vascular endothelial growth factor } \\ \text { HIF-1 } & \text { Hypoxia-inducible factor 1 } \\ \text { TUFT1 } & \text { Tuftelin1 } \\ \text { Hh } & \text { Hedgehog } \\ \text { HGF } & \text { Hepatocyte growth factor } \\ \text { EMT } & \text { Epithelial-mesenchymal transition } \\ \text { EGF } & \text { Epidermal growth factor } \\ \text { FGF } & \text { Fibroblast growth factor } \\ \text { EPM } & \text { Epimorphin } \\ \text { MMPs } & \text { Matrix metalloproteinases } \\ \text { TIMPs } & \text { Tissue inhibitor of metalloproteases } \\ \text { CAFs } & \text { Cancer-associated fibroblasts } \\ \text { NK } & \text { Natural killer } \\ \text { Treg } & \text { Regulatory T cells } \\ & \end{array}$

\section{References}

1. World Health Organization. Global Hepatitis Report 2017; World Health Organization: Geneva, Switzerland, 2017.

2. Younossi, Z.M.; Koenig, A.B.; Abdelatif, D.; Fazel, Y.; Henry, L.; Wymer, M. Global epidemiology of nonalcoholic fatty liver disease-Meta-analytic assessment of prevalence, incidence, and outcomes. Hepatology 2016, 64, 73-84. [CrossRef]

3. Chalasani, N.; Younossi, Z.; Lavine, J.E.; Charlton, M.; Cusi, K.; Rinella, M.; Harrison, S.A.; Brunt, E.M.; Sanyal, A.J. The diagnosis and management of nonalcoholic fatty liver disease: Practice guidance from the American Association for the Study of Liver Diseases. Hepatology 2018, 67, 328-357. [CrossRef]

4. European Association for the Study of the Liver (EASL); European Association for the Study of Diabetes (EASD); European Association for the Study of Obesity (EASO). EASL-EASD-EASO Clinical Practice Guidelines for the management of non-alcoholic fatty liver disease. J. Hepatol. 2016, 64, 1388-1402. [CrossRef]

5. Liew, Z.-H.; Goh, G.B.; Hao, Y.; Chang, P.-E.; Tan, C.-K. Comparison of Hepatocellular Carcinoma in Patients with Cryptogenic Versus Hepatitis B Etiology: A Study of 1079 Cases Over 3 Decades. Dig. Dis. Sci. 2019, 64, 585-590. [CrossRef]

6. Paradis, V.; Zalinski, S.; Chelbi, E.; Guedj, N.; Degos, F.; Vilgrain, V.; Bedossa, P.; Belghiti, J. Hepatocellular carcinomas in patients with metabolic syndrome often develop without significant liver fibrosis: A pathological analysis. Hepatology 2009, 49, 851-859. [CrossRef]

7. Stine, J.G.; Wentworth, B.J.; Zimmet, A.; Rinella, M.E.; Loomba, R.; Caldwell, S.H.; Argo, C.K. Systematic review with meta-analysis: Risk of hepatocellular carcinoma in non-alcoholic steatohepatitis without cirrhosis compared to other liver diseases. Aliment. Pharmacol. Ther. 2018, 48, 696-703. [CrossRef]

8. Ekstedt, M.; Hagström, H.; Nasr, P.; Fredrikson, M.; Stål, P.; Kechagias, S.; Hultcrantz, R. Fibrosis stage is the strongest predictor for disease-specific mortality in NAFLD after up to 33 years of follow-up. Hepatology 2015, 61, 1547-1554. [CrossRef] 
9. Llovet, J.M.; Zucman-Rossi, J.; Pikarsky, E.; Sangro, B.; Schwartz, M.; Sherman, M.; Gores, G. Hepatocellular carcinoma. Nat. Rev. Dis. Prim. 2016, 2, 16018. [CrossRef]

10. White, D.L.; Kanwal, F.; El-Serag, H.B. Association between nonalcoholic fatty liver disease and risk for hepatocellular cancer, based on systematic review. Clin. Gastroenterol. Hepatol. 2012, 10, 1342-1359. [CrossRef]

11. Farazi, P.A.; DePinho, R.A. Hepatocellular carcinoma pathogenesis: From genes to environment. Nat. Rev. Cancer 2006, 6, 674-687. [CrossRef]

12. Febbraio, M.A.; Reibe, S.; Shalapour, S.; Ooi, G.J.; Watt, M.J.; Karin, M. Preclinical Models for Studying NASH-Driven HCC: How Useful Are They? Cell Metab. 2019, 29, 18-26. [CrossRef]

13. Tilg, H.; Moschen, A.R. Evolution of inflammation in nonalcoholic fatty liver disease: The multiple parallel hits hypothesis. Hepatology 2010, 52, 1836-1846. [CrossRef]

14. De Minicis, S.; Agostinelli, L.; Rychlicki, C.; Sorice, G.P.; Saccomanno, S.; Candelaresi, C.; Giaccari, A.; Trozzi, L.; Pierantonelli, I.; Mingarelli, E.; et al. HCC development is associated to peripheral insulin resistance in a mouse model of NASH. PLoS ONE 2014, 9, e97136. [CrossRef]

15. Peverill, W.; Powell, L.W.; Skoien, R. Evolving concepts in the pathogenesis of NASH: Beyond steatosis and inflammation. Int. J. Mol. Sci. 2014, 15, 8591-8638. [CrossRef]

16. Wong, V.W.-S.; Chitturi, S.; Wong, G.L.-H.; Yu, J.; Chan, H.L.-Y.; Farrell, G.C. Pathogenesis and novel treatment options for non-alcoholic steatohepatitis. Lancet Gastroenterol. Hepatol. 2016, 1, 56-67. [CrossRef]

17. Capece, D.; Fischietti, M.; Verzella, D.; Gaggiano, A.; Cicciarelli, G.; Tessitore, A.; Zazzeroni, F.; Alesse, E. The Inflammatory Microenvironment in Hepatocellular Carcinoma: A Pivotal Role for Tumor-Associated Macrophages. Biomed. Res. Int. 2013, 2013, 187204. [CrossRef]

18. Ma, C.; Kesarwala, A.H.; Eggert, T.; Medina-Echeverz, J.; Kleiner, D.E.; Jin, P.; Stroncek, D.F.; Terabe, M.; Kapoor, V.; ElGindi, M.; et al. NAFLD causes selective CD4+ T lymphocyte loss and promotes hepatocarcinogenesis. Nature 2016, 531, 253-257. [CrossRef]

19. Affo, S.; Yu, L.-X.; Schwabe, R.F. The Role of Cancer-Associated Fibroblasts and Fibrosis in Liver Cancer. Annu. Rev. Pathol. 2017, 12, 153-186. [CrossRef]

20. Park, E.J.; Lee, J.H.; Yu, G.-Y.; He, G.; Ali, S.R.; Holzer, R.G.; Osterreicher, C.H.; Takahashi, H.; Karin, M. Dietary and genetic obesity promote liver inflammation and tumorigenesis by enhancing IL-6 and TNF expression. Cell 2010, 140, 197-208. [CrossRef]

21. Grohmann, M.; Wiede, F.; Dodd, G.T. Obesity Drives STAT-1-Dependent NASH and STAT-3-Dependent HCC. Cell 2018, 175, 1289-1306. [CrossRef]

22. Dapito, D.H.; Mencin, A.; Gwak, G.-Y. Promotion of Hepatocellular Carcinoma by the Intestinal Microbiota and TLR4. Cancer Cell 2012, 21, 504-516. [CrossRef]

23. Carloni, V.; Luong, T.V.; Rombouts, K. Hepatic stellate cells and extracellular matrix in hepatocellular carcinoma: More complicated than ever. Liver Int. 2014, 34, 834-843. [CrossRef]

24. Michalopoulos, G.K. Liver regeneration. J. Cell. Physiol. 2007, 213, 286-300. [CrossRef]

25. Seki, E.; Schwabe, R.F. Hepatic inflammation and fibrosis: Functional links and key pathways. Hepatology 2015, 61, 1066-1079. [CrossRef]

26. Stickel, F.; Hellerbrand, C. Non-alcoholic fatty liver disease as a risk factor for hepatocellular carcinoma: Mechanisms and implications. Gut 2010, 59, 1303-1307. [CrossRef]

27. Zhang, C.-Y.; Yuan, W.-G.; He, P.; Lei, J.-H.; Wang, C.-X. Liver fibrosis and hepatic stellate cells: Etiology, pathological hallmarks and therapeutic targets. World J. Gastroenterol. 2016, 22, 10512-10522. [CrossRef]

28. Leitinger, B.; Hohenester, E. Mammalian collagen receptors. Matrix Biol. 2007, 26, 146-155. [CrossRef]

29. Patsenker, E.; Stickel, F. Role of integrins in fibrosing liver diseases. Am. J. Physiol. Gastrointest. Liver Physiol. 2011, 301, G425-G434. [CrossRef]

30. Hernandez-Gea, V.; Friedman, S.L. Pathogenesis of Liver Fibrosis. Annu. Rev. Pathol. Mech. Dis. 2011, 6, 425-456. [CrossRef]

31. Howe, A.; Aplin, A.E.; Alahari, S.K.; Juliano, R.L. Integrin signaling and cell growth control. Curr. Opin. Cell. Biol. 1998, 10, 220-231. [CrossRef]

32. Yang, C.; Zeisberg, M.; Lively, J.C.; Nyberg, P.; Afdhal, N.; Kalluri, R. Integrin alpha1beta1 and alpha2beta1 are the key regulators of hepatocarcinoma cell invasion across the fibrotic matrix microenvironment. Cancer Res. 2003, 63, 8312-8317.

33. Wu, Y.; Qiao, X.; Qiao, S.; Yu, L. Targeting integrins in hepatocellular carcinoma. Expert Opin. Ther. Targets 2011, 15, 421-437. [CrossRef] 
34. Zheng, X.; Liu, W.; Xiang, J.; Liu, P.; Ke, M.; Wang, B.; Wu, R.; Lv, Y. Collagen I promotes hepatocellular carcinoma cell proliferation by regulating integrin $\beta 1 / F A K$ signaling pathway in nonalcoholic fatty liver. Oncotarget 2017, 8, 95586-95595. [CrossRef]

35. Walsh, L.A.; Nawshad, A.; Medici, D. Discoidin domain receptor 2 is a critical regulator of epithelial-mesenchymal transition. Matrix Biol. 2011, 30, 243-247. [CrossRef]

36. Zhao, H.; Bian, H.; Bu, X.; Zhang, S.; Zhang, P.; Yu, J.; Lai, X.; Li, D.; Zhu, C.; Yao, L.; et al. Targeting of Discoidin Domain Receptor 2 (DDR2) Prevents Myofibroblast Activation and Neovessel Formation During Pulmonary Fibrosis. Mol. Ther. 2016, 24, 1734-1744. [CrossRef]

37. Wells, R.G. The role of matrix stiffness in regulating cell behavior. Hepatology 2008, 47, 1394-1400. [CrossRef]

38. Singh, S.; Fujii, L.L.; Murad, M.H.; Wang, Z.; Asrani, S.K.; Ehman, R.L.; Kamath, P.S.; Talwalkar, J.A. Liver stiffness is associated with risk of decompensation, liver cancer, and death in patients with chronic liver diseases: A systematic review and meta-analysis. Clin. Gastroenterol. Hepatol. 2013, 11, 1573-1584. [CrossRef]

39. Mouw, J.K.; Yui, Y.; Damiano, L.; Bainer, R.O.; Lakins, J.N.; Acerbi, I.; Ou, G.; Wijekoon, A.C.; Levental, K.R.; Gilbert, P.M.; et al. Tissue mechanics modulate microRNA-dependent PTEN expression to regulate malignant progression. Nat. Med. 2014, 20, 360-367. [CrossRef]

40. Ulrich, T.A.; de Juan Pardo, E.M.; Kumar, S. The mechanical rigidity of the extracellular matrix regulates the structure, motility, and proliferation of glioma cells. Cancer Res. 2009, 69, 4167-4174. [CrossRef]

41. You, Y.; Zheng, Q.; Dong, Y.; Wang, Y.; Zhang, L.; Xue, T.; Xie, X.; Hu, C.; Wang, Z.; Chen, R.; et al. Higher Matrix Stiffness Upregulates Osteopontin Expression in Hepatocellular Carcinoma Cells Mediated by Integrin $\beta 1 / G S K 3 \beta / \beta$-Catenin Signaling Pathway. PLoS ONE 2015, 10, e0134243. [CrossRef]

42. Schrader, J.; Gordon-Walker, T.T.; Aucott, R.L.; van Deemter, M.; Quaas, A.; Walsh, S.; Benten, D.; Forbes, S.J.; Wells, R.G.; Iredale, J.P. Matrix stiffness modulates proliferation, chemotherapeutic response, and dormancy in hepatocellular carcinoma cells. Hepatology 2011, 53, 1192-1205. [CrossRef]

43. Dong, Y.; Xie, X.; Wang, Z.; Hu, C.; Zheng, Q.; Wang, Y.; Chen, R.; Xue, T.; Chen, J.; Gao, D.; et al. Increasing matrix stiffness upregulates vascular endothelial growth factor expression in hepatocellular carcinoma cells mediated by integrin $\beta 1$. Biochem. Biophys. Res. Commun. 2014, 444, 427-432. [CrossRef]

44. You, Y.; Zheng, Q.; Dong, Y.; Xie, X.; Wang, Y.; Wu, S.; Zhang, L.; Wang, Y.; Xue, T.; Wang, Z.; et al. Matrix stiffness-mediated effects on stemness characteristics occurring in HCC cells. Oncotarget 2016, 7, 32221-32231. [CrossRef]

45. Naim, A.; Pan, Q.; Baig, M.S. Matrix Metalloproteinases (MMPs) in Liver Diseases. J. Clin. Exp. Hepatol. 2017, 7, 367-372. [CrossRef]

46. Rodríguez, D.; Morrison, C.J.; Overall, C.M. Matrix metalloproteinases: What do they not do? New substrates and biological roles identified by murine models and proteomics. Biochim. Biophys. Acta 2010, 1803, 39-54. [CrossRef]

47. Murphy, G.; Docherty, A.J.P. The Matrix Metalloproteinases and Their Inhibitors. Am. J. Respir. Cell. Mol. Biol. 1992, 7, 120-125. [CrossRef]

48. Wallace, M.C.; Friedman, S.L. Hepatic fibrosis and the microenvironment: Fertile soil for hepatocellular carcinoma development. Gene Expr. 2014, 16, 77-84. [CrossRef]

49. Song, T.; Dou, C.; Jia, Y.; Tu, K.; Zheng, X. TIMP-1 activated carcinoma-associated fibroblasts inhibit tumor apoptosis by activating SDF1/CXCR4 signaling in hepatocellular carcinoma. Oncotarget 2015, 6, 12061-12079. [CrossRef]

50. Ando, W.; Yokomori, H.; Tsutsui, N.; Yamanouchi, E.; Suzuki, Y.; Oda, M.; Inagaki, Y.; Otori, K.; Okazaki, I. Serum matrix metalloproteinase-1 level represents disease activity as opposed to fibrosis in patients with histologically proven nonalcoholic steatohepatitis. Clin. Mol. Hepatol. 2018, 24, 61-76. [CrossRef]

51. O'Rourke, J.M.; Sagar, V.M.; Shah, T. Carcinogenesis on the background of liver fibrosis: Implications for the management of hepatocellular cancer. World J. Gastroenterol. 2018, 24, 4436-4447. [CrossRef]

52. Harris, A.L. Hypoxia-A key regulatory factor in tumour growth. Nat. Rev. Cancer 2002, 2, 38-47. [CrossRef]

53. Yu, D.-C.; Chen, J.; Ding, Y.-T. Hypoxic and highly angiogenic non-tumor tissues surrounding hepatocellular carcinoma: The 'niche' of endothelial progenitor cells. Int. J. Mol. Sci. 2010, 11, 2901-2909. [CrossRef]

54. Semenza, G.L. Oxygen Sensing, Homeostasis, and Disease. N. Engl. J. Med. 2011, 365, 537-547. [CrossRef]

55. Lichtenberger, B.M.; Tan, P.K.; Niederleithner, H.; Ferrara, N.; Petzelbauer, P.; Sibilia, M. Autocrine VEGF signaling synergizes with EGFR in tumor cells to promote epithelial cancer development. Cell 2010, 140, 268-279. [CrossRef] 
56. Hernandez-Gea, V.; Toffanin, S.; Friedman, S.L.; Llovet, J.M. Role of the microenvironment in the pathogenesis and treatment of hepatocellular carcinoma. Gastroenterology 2013, 144, 512-527. [CrossRef]

57. Leiser, Y.; Blumenfeld, A.; Haze, A.; Dafni, L.; Taylor, A.L.; Rosenfeld, E.; Fermon, E.; Gruenbaum-Cohen, Y.; Shay, B.; Deutsch, D. Localization, quantification, and characterization of tuftelin in soft tissues. Anat. Rec. 2007, 290, 449-454. [CrossRef]

58. Dou, C.; Zhou, Z.; Xu, Q.; Liu, Z.; Zeng, Y.; Wang, Y.; Li, Q.; Wang, L.; Yang, W.; Liu, Q.; et al. Hypoxia-induced TUFT1 promotes the growth and metastasis of hepatocellular carcinoma by activating the $\mathrm{Ca}^{2+} / \mathrm{PI} 3 \mathrm{~K} / \mathrm{AKT}$ pathway. Oncogene 2018, 38, 1239-1255. [CrossRef]

59. McMahon, A.P.; Ingham, P.W.; Tabin, C.J. Developmental roles and clinical significance of hedgehog signaling. Curr. Top. Dev. Biol. 2003, 53, 1-114.

60. Choi, S.S.; Omenetti, A.; Syn, W.-K.; Diehl, A.M. The role of Hedgehog signaling in fibrogenic liver repair. Int. J. Biochem. Cell. Biol. 2011, 43, 238-244. [CrossRef]

61. Ochoa, B.; Syn, W.-K.; Delgado, I.; Karaca, G.F.; Jung, Y.; Wang, J.; Zubiaga, A.M.; Fresnedo, O.; Omenetti, A.; Zdanowicz, M.; et al. Hedgehog signaling is critical for normal liver regeneration after partial hepatectomy in mice. Hepatology 2010, 51, 1712-1723. [CrossRef]

62. Zheng, X.; Zeng, W.; Gai, X.; Xu, Q.; Li, C.; Liang, Z.; Tuo, H.; Liu, Q. Role of the Hedgehog pathway in hepatocellular carcinoma (Review). Oncol. Rep. 2013, 30, 2020-2026. [CrossRef]

63. Zhou, X.; Wang, P.; Ma, Z.; Li, M.; Teng, X.; Sun, L.; Wan, G.; Li, Y.; Guo, L.; Liu, H. Novel Interplay Between Sonic Hedgehog and Transforming Growth Factor- $\beta 1$ in Human Nonalcoholic Steatohepatitis. Appl. Immunohistochem. Mol. Morphol. AIMM 2019. [CrossRef]

64. Philips, G.M.; Chan, I.S.; Swiderska, M.; Schroder, V.T.; Guy, C.; Karaca, G.F.; Moylan, C.; Venkatraman, T.; Feuerlein, S.; Syn, W-K.; et al. Hedgehog signaling antagonist promotes regression of both liver fibrosis and hepatocellular carcinoma in a murine model of primary liver cancer. PLoS ONE 2011, 6, e23943. [CrossRef]

65. Carpino, G.; Renzi, A.; Onori, P.; Gaudio, E. Role of Hepatic Progenitor Cells in Nonalcoholic Fatty Liver Disease Development: Cellular Cross-Talks and Molecular Networks. Int. J. Mol. Sci. 2013, 14, 20112-20130. [CrossRef]

66. Mishra, L.; Banker, T.; Murray, J.; Byers, S.; Thenappan, A.; He, A.R.; Shetty, K.; Johnson, L.; Reddy, E.P. Liver stem cells and hepatocellular carcinoma. Hepatology 2009, 49, 318-329. [CrossRef]

67. Clevers, H. The intestinal crypt, a prototype stem cell compartment. Cell 2013, 154, 274-284. [CrossRef]

68. Nobili, V.; Carpino, G.; Alisi, A.; Franchitto, A.; Alpini, G.; de Vito, R.; Onori, P.; Alvaro, D.; Gaudio, E. Hepatic progenitor cells activation, fibrosis, and adipokines production in pediatric nonalcoholic fatty liver disease. Hepatology 2012, 56, 2142-2153. [CrossRef]

69. Richardson, M.M.; Jonsson, J.R.; Powell, E.; Brunt, E.M.; Neuschwander-Tetri, B.A.; Bhathal, P.S.; Dixon, J.B.; Weltman, M.D.; Tilg, H.; Moschen, A.R.; et al. Progressive fibrosis in nonalcoholic steatohepatitis: Association with altered regeneration and a ductular reaction. Gastroenterology 2007, 133, 80-90. [CrossRef]

70. Czaja, M.J. Function of Autophagy in Nonalcoholic Fatty Liver Disease. Dig. Dis. Sci. 2016, 61, $1304-1313$. [CrossRef]

71. Mao, Y.; Yu, F.; Wang, J.; Guo, C.; Fan, X. Autophagy: A new target for nonalcoholic fatty liver disease therapy. Hepat. Med. 2016, 8, 27-37. [CrossRef]

72. Thoen, L.F.R.; Guimarães, E.L.M.; Dollé, L.; Mannaerts, I.; Najimi, M.; Sokal, E.; van Grunsven, L.A. A role for autophagy during hepatic stellate cell activation. J. Hepatol. 2011, 55, 1353-1360. [CrossRef]

73. Elmansi, A.; El-Karef, A.; Shishtawy, M.; Eissa, L. Hepatoprotective Effect of Curcumin on Hepatocellular Carcinoma Through Autophagic and Apoptic Pathways. Ann. Hepatol. 2017, 16, 607-618. [CrossRef]

74. Takamura, A.; Komatsu, M.; Hara, T.; Sakamoto, A.; Kishi, C.; Waguri, S.; Eishi, Y.; Hino, O.; Tanaka, K.; Mizushima, N. Autophagy-deficient mice develop multiple liver tumors. Genes Dev. 2011, 25, 795-800. [CrossRef]

75. Sun, K.; Xu, L.; Jing, Y.; Han, Z.; Chen, X.; Cai, C.; Zhao, P.; Zhao, X.; Yang, L.; Wei, L. Autophagy-deficient Kupffer cells promote tumorigenesis by enhancing mtROS-NF- $k$ B-IL $1 \alpha / \beta$-dependent inflammation and fibrosis during the preneoplastic stage of hepatocarcinogenesis. Cancer Lett. 2017, 388, 198-207. [CrossRef]

76. Ringelhan, M.; Pfister, D.; O'Connor, T.; Pikarsky, E.; Heikenwalder, M. The immunology of hepatocellular carcinoma. Nat. Immunol. 2018, 19, 222-232. [CrossRef]

77. Lanthier, N. Targeting Kupffer cells in non-alcoholic fatty liver disease/non-alcoholic steatohepatitis: Why and how? World J. Hepatol. 2015, 7, 2184-2188. [CrossRef] 
78. Ganz, M.; Szabo, G. Immune and inflammatory pathways in NASH. Hepatol. Int. 2013, 7 (Suppl. S2), 771-781. [CrossRef]

79. Kong, L.; Zhou, Y.; Bu, H.; Lv, T.; Shi, Y.; Yang, J. Deletion of interleukin-6 in monocytes/macrophages suppresses the initiation of hepatocellular carcinoma in mice. J. Exp. Clin. Cancer Res. 2016, 35, 131. [CrossRef]

80. Kubes, P.; Mehal, W.Z. Sterile Inflammation in the Liver. Gastroenterology 2012, 143, 1158-1172. [CrossRef]

81. Koh, M.Y.; Gagea, M.; Sargis, T.; Lemos, R.; Grandjean, G.; Charbono, A.; Bekiaris, V.; Sedy, J.; Kiriakova, G.; Liu, X.; et al. A new HIF-1 $\alpha /$ RANTES-driven pathway to hepatocellular carcinoma mediated by germline haploinsufficiency of SART1/HAF in mice. Hepatology 2016, 63, 1576-1591. [CrossRef]

82. Cai, J.; Zhang, X.-J.; Li, H. The Role of Innate Immune Cells in Nonalcoholic Steatohepatitis. Hepatology 2019. [CrossRef]

83. Wolf, M.J.; Adili, A.; Piotrowitz, K.; Abdullah, Z.; Boege, Y.; Stemmer, K.; Ringelhan, M.; Simonavicius, N.; Egger, M.; Wohlleber, D.; et al. Metabolic activation of intrahepatic CD8+ T cells and NKT cells causes nonalcoholic steatohepatitis and liver cancer via cross-talk with hepatocytes. Cancer Cell 2014, 26, 549-564. [CrossRef]

84. Nati, M.; Haddad, D.; Birkenfeld, A.L.; Koch, C.A.; Chavakis, T.; Chatzigeorgiou, A. The role of immune cells in metabolism-related liver inflammation and development of non-alcoholic steatohepatitis (NASH). Rev. Endocr. Metab. Disord. 2016, 17, 29-39. [CrossRef]

85. Tian, Z.; Chen, Y.; Gao, B. Natural killer cells in liver disease. Hepatology 2013, 57, 1654-1662. [CrossRef]

86. Jeong, W.-I.; Park, O.; Suh, Y.-G.; Byun, J.-S.; Park, S.-Y.; Choi, E.; Kim, J.-K.; Ko, H.; Wang, H.; Miller, A.M.; et al. Suppression of innate immunity (natural killer cell/interferon- $\gamma$ ) in the advanced stages of liver fibrosis in mice. Hepatology 2011, 53, 1342-1351. [CrossRef]

87. Male, V.; Stegmann, K.; Easom, N.; Maini, M. Natural Killer Cells in Liver Disease. Semin. Liver Dis. 2017, 37, 198-209. [CrossRef]

88. Albertsson, P.A.; Basse, P.H.; Hokland, M.; Goldfarb, R.H.; Nagelkerke, J.F.; Nannmark, U.; Kuppen, P.J.K. NK cells and the tumour microenvironment: Implications for NK-cell function and anti-tumour activity. Trends Immunol. 2003, 24, 603-609. [CrossRef]

89. Sachdeva, M.; Chawla, Y.K.; Arora, S.K. Immunology of hepatocellular carcinoma. World J. Hepatol. 2015, 7, 2080-2090. [CrossRef]

90. Hassin, D.; Garber, O.G.; Meiraz, A.; Schiffenbauer, Y.S.; Berke, G. Cytotoxic T lymphocyte perforin and Fas ligand working in concert even when Fas ligand lytic action is still not detectable. Immunology 2011, 133, 190-196. [CrossRef]

91. Lucifora, J.; Xia, Y.; Reisinger, F.; Zhang, K.; Stadler, D.; Cheng, X.; Sprinzl, M.F.; Koppensteiner, H.; Makowska, Z.; Volz, T.; et al. Specific and Nonhepatotoxic Degradation of Nuclear Hepatitis B Virus cccDNA. Science 2014, 343, 1221-1228. [CrossRef]

92. Endig, J.; Buitrago-Molina, L.E.; Marhenke, S.; Marhenke, S.; Reisinger, F.; Saborowski, A.; Schütt, J.; Limbourg, F.; Könecke, C.; Schreder, A.; et al. Dual Role of the Adaptive Immune System in Liver Injury and Hepatocellular Carcinoma Development. Cancer Cell 2016, 30, 308-323. [CrossRef]

93. Shalapour, S.; Lin, X.-J.; Bastian, I.N.; Brain, J.; Burt, A.D.; Aksenov, A.A.; Vrbanac, A.F.; Li, W.; Perkins, A.; Matsutani, T; et al. Inflammation-induced IgA+ cells dismantle anti-liver cancer immunity. Nature 2017, 551, 340-345. [CrossRef]

94. Rakhra, K.; Bachireddy, P.; Zabuawala, T.; Zeiser, R.; Xu, L.; Kopelman, A.; Fan, A.C.; Yang, Q.; Braunstein, L.; Crosby, E.; et al. CD4(+) T cells contribute to the remodeling of the microenvironment required for sustained tumor regression upon oncogene inactivation. Cancer Cell 2010, 18, 485-498. [CrossRef]

95. Fu, J.; Zhang, Z.; Zhou, L.; Qi, Z.; Xing, S.; Lv, J.; Shi, J.; Fu, B.; Liu, Z.; Zhang, J.-Y.; et al. Impairment of CD4+ cytotoxic $\mathrm{T}$ cells predicts poor survival and high recurrence rates in patients with hepatocellular carcinoma. Hepatology 2013, 58, 139-149. [CrossRef]

96. Shen, Y.; Wei, Y.; Wang, Z.; Jing, Y.; He, H.; Yuan, J.; Li, R.; Zhao, Q.; Wei, L.; Yang, T.; et al. TGF- $\beta$ regulates hepatocellular carcinoma progression by inducing Treg cell polarization. Cell. Physiol. Biochem. 2015, 35, 1623-1632. [CrossRef]

97. Fu, J.; Xu, D.; Liu, Z.; Shi, M.; Zhao, P.; Fu, B.; Zhang, Z.; Yang, H.; Zhang, H.; Zhou, C.; et al. Increased regulatory $\mathrm{T}$ cells correlate with CD8 T-cell impairment and poor survival in hepatocellular carcinoma patients. Gastroenterology 2007, 132, 2328-2339. [CrossRef] 
98. McPherson, S.; Henderson, E.; Burt, A.D.; Day, C.P.; Anstee, Q.M. Serum immunoglobulin levels predict fibrosis in patients with non-alcoholic fatty liver disease. J. Hepatol. 2014, 60, 1055-1062. [CrossRef]

99. Shalapour, S.; Font-Burgada, J.; Di Caro, G.; Zhong, Z.; Sanchez-Lopez, E.; Dhar, D.; Willimsky, G.; Ammirante, M.; Strasner, A.; Hansel, D.E.; et al. Immunosuppressive plasma cells impede T-cell-dependent immunogenic chemotherapy. Nature 2015, 521, 94-98. [CrossRef]

100. Wang, H.; Chen, L. Tumor microenviroment and hepatocellular carcinoma metastasis. J. Gastroenterol. Hepatol. 2013, 28, 43-48. [CrossRef]

101. Kocabayoglu, P.; Friedman, S.L. Cellular basis of hepatic fibrosis and its role in inflammation and cancer. Front. Biosci. (Schol. Ed.) 2013, 5, 217-230. [CrossRef]

102. Vlodavsky, I.; Miao, H.Q.; Medalion, B.; Danagher, P.; Ron, D. Involvement of heparan sulfate and related molecules in sequestration and growth promoting activity of fibroblast growth factor. Cancer Metastasis Rev. 1996, 15, 177-186. [CrossRef]

103. Levental, K.R.; Yu, H.; Kass, L.; Lakins, J.N.; Egeblad, M.; Erler, J.T.; Fong, S.F.T.; Csiszar, K.; Giaccia, A.; Weninger, W.; et al. Matrix crosslinking forces tumor progression by enhancing integrin signaling. Cell 2009, 139, 891-906. [CrossRef]

104. Campbell, J.S.; Hughes, S.D.; Gilbertson, D.G.; Palmer, T.E.; Holdren, M.S.; Haran, A.C.; Odell, M.M.; Bauer, R.L.; Ren, H.-P.; Haugen, H.S.; et al. Platelet-derived growth factor C induces liver fibrosis, steatosis, and hepatocellular carcinoma. Proc. Natl. Acad. Sci. USA 2005, 102, 3389-3394. [CrossRef]

105. Kelly, J.D.; Haldeman, B.A.; Grant, F.J.; Murray, M.J.; Seifert, R.A.; Bowen-Pope, D.F.; Cooper, J.A.; Kazlauskas, A. Platelet-derived growth factor (PDGF) stimulates PDGF receptor subunit dimerization and intersubunit trans-phosphorylation. J. Biol. Chem. 1991, 266, 8987-8992.

106. Wright, J.H.; Johnson, M.M.; Shimizu-Albergine, M. Paracrine activation of hepatic stellate cells in platelet-derived growth factor $\mathrm{C}$ transgenic mice: Evidence for stromal induction of hepatocellular carcinoma. Int. J. Cancer 2014, 134, 778-788. [CrossRef]

107. Jia, Y.-L.; Shi, L.; Zhou, J.-N.; Fu, C.-J.; Chen, L.; Yuan, H.-F.; Wang, Y.-F.; Yan, X.-L.; Xu, Y.-C.; Zeng, Q.; et al. Epimorphin promotes human hepatocellular carcinoma invasion and metastasis through activation of focal adhesion kinase/extracellular signal-regulated kinase/matrix metalloproteinase-9 axis. Hepatology 2011, 54, 1808-1818. [CrossRef]

108. Imai, Y.; Yoshida, O.; Watanabe, T.; Yukimoto, A.; Koizumi, Y.; Ikeda, Y.; Tokumoto, Y.; Hirooka, M.; Abe, M.; Hiasa, Y. Stimulated hepatic stellate cell promotes progression of hepatocellular carcinoma due to protein kinase R activation. PLoS ONE 2019, 14, e0212589. [CrossRef]

109. Kubo, N.; Araki, K.; Kuwano, H.; Shirabe, K. Cancer-associated fibroblasts in hepatocellular carcinoma. World J. Gastroenterol. 2016, 22, 6841-6850. [CrossRef]

110. Cesselli, D.; Beltrami, A.P.; Poz, A.; Marzinotto, S.; Comisso, E.; Bergamin, N.; Bourkoula, E.; Pucer, A.; Puppato, E.; Toffoletto, B.; et al. Role of tumor associated fibroblasts in human liver regeneration, cirrhosis, and cancer. Int. J. Hepatol. 2011, 2011, 120925. [CrossRef]

111. Neaud, V.; Faouzi, S.; Guirouilh, J.; Le Bail, B.; Balabaud, C.; Bioulac-Sage, P.; Rosenbaum, J. Human hepatic myofibroblasts increase invasiveness of hepatocellular carcinoma cells: Evidence for a role of hepatocyte growth factor. Hepatology 1997, 26, 1458-1466. [CrossRef]

112. Feng, T.; Yu, H.; Xia, Q.; Ma, Y.; Yin, H.; Shen, Y.; Liu, X. Cross-talk mechanism between endothelial cells and hepatocellular carcinoma cells via growth factors and integrin pathway promotes tumor angiogenesis and cell migration. Oncotarget 2017, 8, 69577-69593. [CrossRef]

113. Kareva, I.; Abou-Slaybi, A.; Dodd, O.; Dashevsky, O.; Klement, G.L. Normal Wound Healing and Tumor Angiogenesis as a Game of Competitive Inhibition. PLoS ONE 2016, 11, e0166655. [CrossRef]

114. Welti, J.; Loges, S.; Dimmeler, S.; Carmeliet, P. Recent molecular discoveries in angiogenesis and antiangiogenic therapies in cancer. J. Clin. Investig. 2013, 123, 3190-3200. [CrossRef]

115. Makarova-Rusher, O.V.; Medina-Echeverz, J.; Duffy, A.G.; Greten, T.F. The yin and yang of evasion and immune activation in HCC. J. Hepatol. 2015, 62, 1420-1429. [CrossRef]

116. Derynck, R.; Zhang, Y.E. Smad-dependent and Smad-independent pathways in TGF-beta family signalling. Nature 2003, 425, 577-584. [CrossRef]

117. Fabregat, I.; Fernando, J.; Mainez, J.; Sancho, P. TGF-beta signaling in cancer treatment. Curr. Pharm. Des. 2014, 20, 2934-2947. [CrossRef] 
118. Wang, Y.; Liu, T.; Tang, W.; Deng, B.; Chen, Y.; Zhu, J.; Shen, X. Hepatocellular Carcinoma Cells Induce Regulatory T Cells and Lead to Poor Prognosis via Production of Transforming Growth Factor- $\beta 1$. Cell. Physiol. Biochem. 2016, 38, 306-318. [CrossRef]

119. Calon, A.; Tauriello, D.V.F.; Batlle, E. TGF-beta in CAF-mediated tumor growth and metastasis. Semin. Cancer Biol. 2014, 25, 15-22. [CrossRef]

120. Fransvea, E.; Angelotti, U.; Antonaci, S.; Giannelli, G. Blocking transforming growth factor-beta up-regulates E-cadherin and reduces migration and invasion of hepatocellular carcinoma cells. Hepatology 2008, 47, 1557-1566. [CrossRef]

121. Mazzocca, A.; Fransvea, E.; Dituri, F.; Lupo, L.; Antonaci, S.; Giannelli, G. Down-regulation of connective tissue growth factor by inhibition of transforming growth factor beta blocks the tumor-stroma cross-talk and tumor progression in hepatocellular carcinoma. Hepatology 2010, 51, 523-534. [CrossRef]

122. Luangmonkong, T.; Suriguga, S.; Bigaeva, E.; Boersema, M.; Oosterhuis, D.; de Jong, K.P.; Schuppan, D.; Mutsaers, H.A.M.; Olinga, P. Evaluating the antifibrotic potency of galunisertib in a human ex vivo model of liver fibrosis. Br. J. Pharmacol. 2017, 174, 3107-3117. [CrossRef]

123. Marra, F.; Tacke, F. Roles for chemokines in liver disease. Gastroenterology 2014, 147, 577-594. [CrossRef]

124. Puengel, T.; Krenkel, O.; Mossanen, J.; Longerich, T.; Lefebvre, E.; Trautwein, C.; Tacke, F. The Dual Ccr2/Ccr5 Antagonist Cenicriviroc Ameliorates Steatohepatitis and Fibrosis in Vivo by Inhibiting the Infiltration of Inflammatory Monocytes into Injured Liver. J. Hepatol. 2016, 64, S160. [CrossRef]

125. Friedman, S.L.; Ratziu, V.; Harrison, S.; Abdelmalek, M.F.; Aithal, G.P.; Caballeria, J.; Francque, S.; Farrell, G.; Kowdley, K.V.; Craxi, A.; et al. A randomized, placebo-controlled trial of cenicriviroc for treatment of nonalcoholic steatohepatitis with fibrosis. Hepatology 2018, 67, 1754-1767. [CrossRef]

126. Llovet, J.M.; Ricci, S.; Mazzaferro, V.; Hilgard, P.; Gane, E.; Blanc, J.-F.; de Oliveira, A.C.; Santoro, A.; Raoul, J.-L.; Forner, A.; et al. Sorafenib in advanced hepatocellular carcinoma. N. Engl. J. Med. 2008, 359, 378-390. [CrossRef]

127. Stefano, J.T.; Pereira, I.V.A.; Torres, M.M.; Bida, P.M.; Coelho, A.M.M.; Xerfan, M.P.; Cogliati, B.; Barbeiro, D.F.; Mazo, D.F.C.; Kubrusly, M.S.; et al. Sorafenib prevents liver fibrosis in a non-alcoholic steatohepatitis (NASH) rodent model. Braz. J. Med. Biol. Res. 2015, 48, 408-414. [CrossRef]

128. Jiménez Calvente, C.; Sehgal, A.; Popov, Y.; Kim, Y.O.; Zevallos, V.; Sahin, U.; Diken, M.; Schuppan, D. Specific hepatic delivery of procollagen $\alpha 1$ (I) small interfering RNA in lipid-like nanoparticles resolves liver fibrosis. Hepatology 2015, 62, 1285-1297. [CrossRef]

129. Schuppan, D.; Ashfaq-Khan, M.; Yang, A.T.; Kim, Y.O. Liver fibrosis: Direct antifibrotic agents and targeted therapies. Matrix Biol. 2018, 68-69, 435-451. [CrossRef]

130. Henderson, N.C.; Arnold, T.D.; Katamura, Y.; Giacomini, M.M.; Rodriguez, J.D.; McCarty, J.H.; Pellicoro, A.; Raschperger, E.; Betsholtz, C.; Ruminski, P.G.; et al. Targeting of $\alpha \mathrm{v}$ integrin identifies a core molecular pathway that regulates fibrosis in several organs. Nat. Med. 2013, 19, 1617-1624. [CrossRef]

131. Becker, L.R.; Aakhus, A.E.; Reich, H.C.; Lee, P.K. A Novel Alternate Dosing of Vismodegib for Treatment of Patients with Advanced Basal Cell Carcinomas. JAMA Dermatol. 2017, 153, 321-322. [CrossRef]

132. Whiteside, T.L.; Demaria, S.; Rodriguez-Ruiz, M.E.; Zarour, H.M.; Melero, I. Emerging Opportunities and Challenges in Cancer Immunotherapy. Clin. Cancer Res. 2016, 22, 1845-1855. [CrossRef]

133. El-Khoueiry, A.B.; Sangro, B.; Yau, T.; Crocenzi, T.S.; Kudo, M.; Hsu, C.; Kim, T.-Y.; Choo, S.-P.; Trojan, J.; Welling, T.H.; et al. Nivolumab in patients with advanced hepatocellular carcinoma (CheckMate 040): An open-label, non-comparative, phase 1/2 dose escalation and expansion trial. Lancet 2017, 389, 2492-2502. [CrossRef]

134. Machado, M.V.; Michelotti, G.A.; Xie, G.; de Almeida, T.P.; Boursier, J.; Bohnic, B.; Guy, C.D.; Diehl, A.M.; Diehl, A.M. Mouse Models of Diet-Induced Nonalcoholic Steatohepatitis Reproduce the Heterogeneity of the Human Disease. PLoS ONE 2015, 10, e0127991. [CrossRef]

135. Asgharpour, A.; Cazanave, S.C.; Pacana, T.; Seneshaw, M.; Vincent, R.; Banini, B.A.; Kumar, D.P.; Daita, K.; Min, H.-K.; Mirshahi, F.; et al. A diet-induced animal model of non-alcoholic fatty liver disease and hepatocellular cancer. J. Hepatol. 2016, 65, 579-588. [CrossRef]

136. Tsuchida, T.; Lee, Y.A.; Fujiwara, N.; Ybanez, M.; Allen, B.; Martins, S.; Fiel, M.I.; Goossens, N.; Chou, H.-I.; Hoshida, Y.; et al. A simple diet- and chemical-induced murine NASH model with rapid progression of steatohepatitis, fibrosis and liver cancer. J. Hepatol. 2018, 69, 385-395. [CrossRef] 
137. Alkreathy, H.M.; Khan, R.A.; Khan, M.R.; Sahreen, S. CCl4 induced genotoxicity and DNA oxidative damages in rats: Hepatoprotective effect of Sonchus arvensis. BMC Complement. Altern. Med. 2014, 14, 452. [CrossRef] 138. Musso, G.; Cassader, M.; Paschetta, E.; Gambino, R. Thiazolidinediones and Advanced Liver Fibrosis in Nonalcoholic Steatohepatitis: A Meta-analysis. JAMA Intern. Med. 2017, 177, 633-640. [CrossRef]

(C) 2019 by the authors. Licensee MDPI, Basel, Switzerland. This article is an open access article distributed under the terms and conditions of the Creative Commons Attribution (CC BY) license (http:/ / creativecommons.org/licenses/by/4.0/). 